University of Nebraska - Lincoln

DigitalCommons@University of Nebraska - Lincoln

Publications, Agencies and Staff of the U.S.

Department of Commerce

U.S. Department of Commerce

2011

\title{
Quality Assessment of Filtered Smoked Yellowfin Tuna (Thunnus albacares) Steaks
}

\author{
Lori F. Pivarnik \\ University of Rhode Island, Pivarnik@uri.edu \\ Cameron Faustman \\ University of Connecticut - Storrs \\ Santiago Rossi \\ University of Rhode Island \\ Surendranath P. Suman \\ University of Kentucky \\ Catherine Palmer \\ University of Rhode Island \\ See next page for additional authors
}

Follow this and additional works at: https://digitalcommons.unl.edu/usdeptcommercepub

Part of the Environmental Sciences Commons

Pivarnik, Lori F.; Faustman, Cameron; Rossi, Santiago; Suman, Surendranath P.; Palmer, Catherine; Richard, Nicole L.; Ellis, P. Christopher; and DiLiberti, Michael, "Quality Assessment of Filtered Smoked Yellowfin Tuna (Thunnus albacares) Steaks" (2011). Publications, Agencies and Staff of the U.S. Department of Commerce. 307.

https://digitalcommons.unl.edu/usdeptcommercepub/307

This Article is brought to you for free and open access by the U.S. Department of Commerce at DigitalCommons@University of Nebraska - Lincoln. It has been accepted for inclusion in Publications, Agencies and Staff of the U.S. Department of Commerce by an authorized administrator of DigitalCommons@University of Nebraska - Lincoln. 


\section{Authors}

Lori F. Pivarnik, Cameron Faustman, Santiago Rossi, Surendranath P. Suman, Catherine Palmer, Nicole L. Richard, P. Christopher Ellis, and Michael DiLiberti 


\title{
Quality Assessment of Filtered Smoked Yellowfin Tuna (Thunnus albacares) Steaks
}

\author{
Lori F. Pivarnik, Cameron Faustman, Santiago Rossi, Surendranath P. Suman, Catherine Palmer, Nicole L. Richard, \\ P. Christopher Ellis, and Michael DiLiberti
}

\begin{abstract}
Filtered smoke (FS) has been used to preserve taste, texture, and/or color in tuna and other fish species. This treatment is particularly important in color preservation during frozen storage. The objective of this study was to compare changes in the quality profiles of FS-treated and untreated (UT) yellowfin tuna (Thunnus albacares) steaks stored in 3 ways: room temperature $\left(21\right.$ to $\left.22^{\circ} \mathrm{C}\right)$, refrigerated $\left(4\right.$ to $\left.5^{\circ} \mathrm{C}\right)$, and iced $\left(0{ }^{\circ} \mathrm{C}\right)$. FS and UT steaks were processed from the same lot of fish and analyzed for chemical, microbiological, lipid oxidation, color, and sensory profiles. Similar trends were seen for microbial proliferation and accumulation of apparent ammonia and total volatile base nitrogen (TVB-N) during the storage temperatures evaluated. Notable exception in quality profile was found in lipid oxidation which was, as expected, lower for treated samples at all storage temperatures for TBARS $(P<0.05)$ and lower or significantly $(P<$ $0.05)$ lower for POV values. FS increased the initial redness value significantly $(P<0.05)$. Unlike UT product, there was no loss of color value concomitant with quality changes for FS-treated tuna for all storage temperatures evaluated.
\end{abstract}

Keywords: carbon monoxide, color, filtered wood smoke, seafood quality, tuna steaks

Practical Application: The overall goal of this project was to evaluate filtered smoked tuna steaks as to the impact on the overall quality profile. As a color-stabilizing technology, it could mask deteriorating quality.

\section{Introduction}

Color of meat and seafood has a strong influence on consumer acceptance. A bright red color is an important quality determinant in seafood, particularly tuna, as the market value is based on this attribute. After being cut and during standard commercial frozen storage of tuna, there is a rapid formation of a brown color (Anderson and Wu 2005). Color changes in tuna, from red/purple to red-brown to brownish-red, reflect the chemical oxidation state of the myoglobin within the muscle. The reduced ferrous heme iron ion $(\mathrm{Fe} 2+)$ in the myoglobin molecule is prone to oxidation to the ferric form $(\mathrm{Fe} 3+)$, which affects the color, taste, and texture (Faustman and Cassens 1990; Chan and others 1998). The use of carbon monoxide (CO) either alone or as part of a filtered wood smoke (FS) process, has been applied to seafood in an effort to maintain the desirable color attributes during storage and transportation. When CO complexes with the heme iron of myoglobin in meat it forms the stable red pigment, carboxymyoglobin. Carboxymyoglobin is more resistant to oxidation than oxymyoglobin because $\mathrm{CO}$ has a stronger binding affinity to the heme iron than oxygen does (Livingston and Brown 1981). Although tuna has been a primary product treated by this process, other seafood

MS 20101210 Submitted 10/25/2010, Accepted 5/25/2011. Authors Pivarnik, Rossi, Palmer, and Richard are with Univ. of Rhode Island, Dept. of Nutrition and Food Sciences, West Kingston, RI, USA. Author Faustman is with Univ. of Connecticut, Dept. of Animal Science, Storrs, CT, U.S.A. Author Suman is with Univ. of Kentucky, Dept. of Animal and Food Sciences, Lexington, KY, U.S.A. Author Ellis is with Rhode Island Dept. of Health, Food Chemistry Lab., Providence, RI, U.S.A. Author DiLiberti is with Natl. Technical Services, USDC/NOAA/NSIP, Gloucester, MA, U.S.A. Direct inquiries to author Pivarnik (E-mail: Pivarnik@uri.edu). products - snapper, mahi mahi, marlin, swordfish, and tilapia-are also being treated to help preserve color. During the FS process, natural wood smoke is filtered to remove all or most of the taste and odor components, and particulate matter from the vapor phase of the smoke. This leaves $\mathrm{CO}$ as a significant component to bind to the heme molecule and "fix" the red color in dark muscle (Kristinsson and others 2006b). In addition, improving myoglobin stability may improve lipid stability. The heme proteins are strong catalysts of lipid oxidation in muscle (Richards and Hultin 2002; Undeland and others 2004). Research on meat and tuna muscle has shown an interaction between oxymyoglobin oxidation and lipid oxidation (Faustman and others 1989; Lee and others 2003). Oxymyoglobin oxidation by-products are prooxidative towards unsaturated fatty acids, and conversely, the process of lipid oxidation can generate chemical species that predispose myoglobin to rapid oxidation (Greene 1969; Greene and others 1971; Faustman and others 2010). FS treatment could result in fewer oxidation products of fatty acids, which in turn, would result in delayed production of off-flavors and off-odors in meat. However, the use of color-stabilizing technologies with fresh meat might mask microbial spoilage (Faustman and others 1989).

Filtered smoke treatment, when compared to UT controls, has been shown by previous research to decrease bacterial load, increase oxidative stability, and increase red color stability in stored tuna (Ludlow and others 2004; Kristinsson and others 2008), mahi mahi (Demir and others 2004; Kristinsson and others 2007), and Spanish mackerel (Garner and Kristinsson 2004). The researchers speculated that $\mathrm{CO}_{2}(21 \%$ of FS) and $\mathrm{CO}(18 \%$ of FS) worked together to reduce and suppress microbial growth and that a variety of other compounds in FS may impart antimicrobial effects. Impacts observed when FS was applied were not always seen when 
pure CO was used (Kristinsson and others 2006a). The application of pure $\mathrm{CO}$ gas on tuna quality resulted in a delay of undesirable color changes when high gas concentration (100\%) was used; low levels (4\%) did not impact color. In addition, FS has been shown to have a greater impact on microbial growth than pure $\mathrm{CO}$ due to possible residual impacts in the muscle tissue (Kristinsson and others 2006b).

Thus far, research has focused on the effects of $\mathrm{CO}$ alone and/or FS treatment on fish quality as delineated by microbial, lipid oxidation and color stability assessments (Garner and Kristinsson 2004; Ludlow and others 2004; Kristinsson and others 2007, 2008). Only mahi-mahi was studied for sensory attributes with semitrained sensory analysts (Kristinsson and others 2008). No study has integrated expert sensory assessments and traditional seafood spoilage indicators (for example, TVB) with microbial, lipid oxidation, and color determinants for a complete quality profile of tuna that has been treated with FS. This additional information would be necessary to more fully assess the impact of FS on perceived quality of seafood. Concerns have been raised regarding quality and safety of these products which may be disguised by a "fresh-looking" piece of fish (Anderson and Wu 2005). The original draft of the Food Safety Enhancement Act (H.R. 3/26/2009; H.R. July 2009) reflected this on-going concern by including a directive for the FDA to conduct a safety assessment on the use of carbon monoxide on meat, poultry, and seafood products. While this order does not appear to be included in the final amended bill, it indicated that there were still concerns about this particular technology on quality and safety of food. Therefore, more information is still needed to completely evaluate the impact of filtered smoke on the indicators of quality of seafood.

The overall goal of this project was to evaluate commercially processed, filtered smoked tuna steaks as to the overall quality profile. Specific objectives included establishing (1) profiles of chemical quality indicators, (2) enumeration of microbial growth, (3) lipid oxidation changes, (4) sensory assessment parameters, and (5) color change and stability.

\section{Materials and Methods}

\section{Raw material}

Yellowfin tuna (Thunnus albacares) was obtained through Clearsmoke ${ }^{\circledR}$ Technologies, Atlanta, Georgia. The fish were caught by long lines in the Gulf of Mexico in December and were headed, gutted, and fins removed on-board. The fish were shipped via ground transportation from Louisiana, packaged in ice, and held under refrigeration upon receipt at the Clearsmoke Technologies facility. The 4 to $5 \mathrm{~d}$ old fish were rated as Grade 2 . Grade 2 tuna is used in the lower end sashimi markets or high end restaurants, where tuna is prepared semi cooked (Bartram 1996; Ledafish 2011). The main differences between Grade 1 and Grade 2 tuna is with respect to red color; where Grade 1 tuna has bright red muscle and translucent flesh (clarity) compared to Grade 2 tuna with red muscle and some translucency (Bartram 1996; Ledafish 2011). Total of 3 whole tuna, from the same lot, were used for this project. One upper and one lower tuna loin from each fish were separated into 2 groups-one that would be treated with FS. and one that would not be treated (UT). Each group contained equal numbers of pieces from upper and lower loins. A total of 48 steaks for FS and UT samples were used for this study and the steaks were sampled randomly. The average weight and thickness measurements were taken on $14(n=14)$ randomly selected tuna steaks for untreated and treated samples. The average weight and thickness of UT steaks were $236.9 \pm 86.2 \mathrm{~g}$ and $20.3 \pm 2.7 \mathrm{~mm}$, respectively. The average weight and thickness of FS steaks were $235 \pm 73.2 \mathrm{~g}$ and $20.0 \pm 3.5 \mathrm{~mm}$, respectively. UT steaks were vacuum-packaged and frozen immediately. Remaining steaks were treated with filtered smoke.

\section{Filtered smoke treatment}

A total of 4 to 6 randomly sampled steaks were placed in a vacuum bag, air removed, and treated with filtered smoke using pilot scale equipment at Clearsmoke Technologies. The smoke contained 16\% CO (verified on-site). Bags were held under refrigeration for about $48 \mathrm{~h}$, flushed, vacuum-packaged, sealed, and frozen after treatment. All UT and FS samples were held for $30 \mathrm{~d}$ and shipped frozen, overnight, to the Univ. of Rhode Island where they were held frozen until storage trials began.

\section{Storage and preparation of fish samples}

All frozen samples were thawed at refrigerated temperature (4 to $\left.5{ }^{\circ} \mathrm{C}\right)$ prior to time/temperature storage trials. Three steak samples were placed next to each other in unclosed, oxygen permeable plastic bags and stored at room temperature $\left(22^{\circ} \mathrm{C}\right)$, refrigerated $\left(4\right.$ to $\left.5^{\circ} \mathrm{C}\right)$, and in ice $\left(0^{\circ} \mathrm{C}\right)$. UT and FS products were packaged separately. Fish stored at room temperature were evenly spaced out in plastic trays under a fume hood. Products held at refrigerated temperatures were stored in plastic trays and spaced evenly. Samples held in ice were positioned upright in an insulated cooler, surrounded by ice with the opening to the plastic bags oriented to prevent melting ice water from entering the bag. A day "zero" represented the first set of samples.

Packages for each sampling interval were assigned a random 3-digit code and duplicate bags of fish samples, each bag with 3 steaks, were selected randomly at each time point. One bag containing samples $(n=3)$ was immediately tested for aerobic plate counts and then vacuum-packaged (Super Vac, Smith Equipment, Clifton, N.J., U.S.A.), frozen and stored at $-70{ }^{\circ} \mathrm{C}$ for chemical analyses. The other package was vacuumpackaged, stored at $-70^{\circ} \mathrm{C}$ until overnight shipment for sensory testing at the Natl. Marine Fisheries Service, Gloucester, Mass., U.S.A.

Samples for color and lipid oxidation were transported on ice to the Univ. of Connecticut. Fish samples were stored and sampled under the same conditions as at the URI facility. Color determinations were made on each steak followed by lipid oxidation measurements.

\section{Microbiological assessment}

Psychrotrophic bacteria counts were obtained by the standard agar plate count per AOAC (1990) method 966.23 and FDA (1995) BAM. Total aerobic plate counts on fish tissue were done aseptically. Approximately one-half of each steak was blended using a Handy-Chopper ${ }^{\mathrm{TM}}$ (Black-Decker, Shelton, Conn., U.S.A.). Total of $11 \mathrm{~g}$ of the blended tissue were transferred into individual sterile Whirlpak bags containing $99 \mathrm{~mL}$ of sterile Butterfields Phosphate buffer and pulsified, using a Pulsifier ${ }^{\mathrm{TM}}$ (Filtaflex Ltd., Almonte, Ontario, Canada) for 60 s. This was followed by standard dilutions and plating using the spread plate technique onto plate count agar and incubated at $25^{\circ} \mathrm{C}$ for $48 \mathrm{~h}$ following accepted methods of sampling, preparation, and enumeration (Banwart 1989; FDA 1995; Venkitanarayanan and others 1997; Jay 2000). Mean values represented the 3 determinations. 


\section{Sample preparation for apparent ammonia and TVB-N} analyses

Vacuum-sealed frozen samples were thawed using cold running water in preparation for chemical analyses. Thawed steaks were homogenized, individually, using a handy-chopper (Black-Decker). Each homogenate was then sampled for apparent ammonia and TVB determinations resulting in 3 measurements. All homogenized samples were vacuum-packaged (Super Vac) in pouches (Market Sales Co., Newton, Mass., U.S.A.) and frozen at $-70{ }^{\circ} \mathrm{C}$ until analysis was performed.

\section{Apparent ammonia by ISE}

Apparent ammonia was determined on all homogenates using the ISE procedure (AOAC 2000) method 999.01 as originally outlined by Pivarnik and others (1998). Briefly, $5 \mathrm{~g}$ of comminuted fish tissue samples were blended with $95 \mathrm{~mL}$ of water for $2 \mathrm{~min}$, and $\mathrm{pH}$ adjusted with $2 \mathrm{~mL}$ alkaline ion-strength adjuster (ISA) solution. The compounds contributing to the ammonia response were immediately determined using a precalibrated Orion model 95-12 ammonia gas-sensing, ion-specific electrode, and an Orion Model 290A portable pH/ISE meter (Thermo Orion, Beverly, Mass., U.S.A.). All results were reported as miligram apparent ammonia per $100 \mathrm{~g}$ of fish tissue (Pivarnik and others 1998).

\section{TVB-N analysis}

TVB analysis was conducted on a double trichloroacetic acid (TCA) extraction. TVB concentrations were determined by distillation and titration as specified by published procedures (Malle and Tao 1987; Malle and Poumeyrol 1989). Briefly, $50 \mathrm{~g}$ comminuted fish were blended in $100 \mathrm{~mL}$ 7.5\% (w/v) TCA solution at high speed for $2 \mathrm{~min}$. The homogenate was filtered through Whatman $\mathrm{nr} 1$ filter paper. A $25 \mathrm{~mL}$ aliquot of the TCA extract was pipetted into a distilling flask ( $250 \mathrm{~mL}$ Tecator digestion tube) and $10 \mathrm{~mL}$ $10 \% \mathrm{NaOH}$ was added. Steam distillation (Tecator Kjeltec Model 1002 distillation unit) lasted until $75 \mathrm{~mL}$ liquid was collected in a $125 \mathrm{~mL}$ Erlenmeyer flask containing $10 \mathrm{~mL}$ Kjeldahl indicator solution ( $4 \mathrm{~g}$ boric acid in distilled water containing $0.7 \mathrm{~mL} 0.1 \%$ alcoholic solution of methyl red and $1.0 \mathrm{~mL} 0.1 \%$ alcoholic solution of bromocresol green diluted to $100 \mathrm{~mL}$ in distilled water) per AOAC (1995) method 980.10. The green alkaline distillate was back-titrated with $0.025 \mathrm{~N}$ sulfuric acid to its original red color.

\section{Lipid oxidation}

The thiobarbituric acid (TBA) procedure of Yin and others (1993) was used to assess lipid oxidation and reported as TBAReactive Substances (TBARS). Analysis of peroxide values (POV) was conducted by a modified procedure of Shantha and Decker (1994). Whole muscle steak samples were stored in vacuum packages for the storage portion of this study to prevent oxygen penetration into the package. For the TBA test, BHA was added into the acid tissue extract to prevent the production of oxidation products during the analytical preparation of the sample. Briefly, triplicate $5 \mathrm{~g}$ samples were each added to $10 \mathrm{~mL}$ distilled water

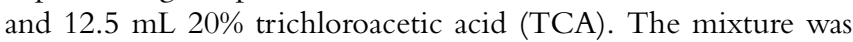
homogenized for $1 \mathrm{~min}$ in a Waring blender and filtered through Whatman nr 1 filter paper. A total of $1 \mathrm{~mL}$ filtrate was mixed with $1 \mathrm{~mL} 20 \mathrm{mM}$ aqueous TBA and incubated at $25^{\circ} \mathrm{C}$ for $21 \mathrm{~h}$. The absorbance was measured at $532 \mathrm{~nm}$ and reported as TBARS.

\section{Color assessment}

$L^{*}$ (lightness), $a^{*}$ (redness), and $b^{*}$ (yellowness) values (Faustman and Phillips 2001) were recorded from 2 different surface locations on the tuna steaks using a Minolta Chromameter CR 200 (Osaka, Japan) calibrated to a standard white plate. Illuminant used was C $(6774 \mathrm{~K})$ and the measuring area was $8 \mathrm{~mm}$. All fish samples were analyzed in their vacuum packages. Total of 3 different measurements were taken across each product surface and averaged to obtain the mean value for each experimental unit. In addition, the color penetration was measured in representative samples. Samples were sliced in half, perpendicular to the long axis of the muscle, and measured $(\mathrm{mm})$ relative to the depth of surface red coloration. This was done over storage to determine if the surface color layer changed in a manner consistent with what has been observed in red meat (Faustman and Cassens 1990).

\section{Expert sensory assessment}

Vacuum-packaged, frozen fish samples were shipped overnight to the USDC/NOAA sensory laboratory in Gloucester, MA. This laboratory fulfilled all of the requirements mandated by the ASTM STP 913 (ISO 1993) guidelines for physical design of sensory evaluation laboratories. Upon arrival, the samples were checked to ensure that the frozen integrity had been maintained and placed in a $-80^{\circ} \mathrm{C}$ freezer and stored for no longer than 1 mo before sensory evaluation of raw product. Prior to a scheduled sensory session, samples were prepared in an odor-free area that was separated from the sensory testing facility. The vacuum-sealed samples were tempered at $4{ }^{\circ} \mathrm{C}$ for $12 \mathrm{~h}$, and brought to room temperature in running water immediately before sensory evaluation. All packages were identified by random 3-digit codes and placed in booths.

Three expert inspectors, internationally calibrated and trained, and who had achieved test scores of greater than $85 \%$ during past testing sessions, were chosen to conduct the sensory assessments on all samples. Each inspector had at least $10 \mathrm{y}$ of practical experience and had been trained by attending a minimum of 3 international free trade harmonization workshops. After training, using a 100 $\mathrm{mm}$ line, each inspector was presented with 120 test samples and had to achieve a score of $85 \%$ or better and "expert" status according to statistical criteria agreed upon by FDA and NMFS in the U.S. and the Canadian Food Inspection Agency (Reilly and York 1993). Each inspector also met International Standards (ISO) for sensory evaluation criteria (ISO 1993). A minimum of 3 sensory experts is required to achieve statistically valid results for quality and decomposition evaluation and to ensure a high degree of acuity and reproducibility (Poste and others 1991; Sims and others 1992; Pivarnik and others 2001). The analysts independently evaluated each sample for appearance, texture, and odor in the raw state. Sample evaluation was conducted in a facility illuminated with artificial daylight and red amber lights.

Analysts evaluated each sample using a standardized ballot developed during international exercises involving harmonization for product sensory standards and criteria that USDC/NOAA seafood analysts had participated in developing. The ballot consisted of the 3-digit sample number, an unstructured 100-mm line scale, a place to indicate whether the sample passed or failed for decomposition, and a space to write any descriptive information for each sample. Overall evaluation, while primarily reflecting odor, incorporated some general textural and appearance qualifiers as verification for the odor assessment. The line scale represented the degree of continuous deterioration of the sample, where $0=$ no deterioration and $100=$ severe decomposition. Samples obtaining sensory scores of greater than 50 were considered unacceptable, as agreed during an International Free Trade agreement workshop and detailed during the harmonization workshops. 
Following independent evaluation, a panel leader collected pass/fail decisions, numerical data, and any terminology that described sensory characteristics.

\section{Statistical analysis}

All assays were determined in triplicate and the results were reported as means. The significance of the differences were determined between treated and untreated samples, at the different temperature storage conditions by two-way analysis of variance (ANOVA) followed by $F$-tests and student $t$-tests using the Excel data analysis tools (Microsoft Excel 2000, Microsoft Corp., Redmond, Wash., U.S.A.). Significance of difference was reported at $P \leq 0.05$.

\section{Results and Discussion}

Microbiological analyses indicated that at time zero, there was a significant $(P<0.05)$ difference between UT and FS samples (Figure 1), where initial microbial concentrations were $3.9 \pm$ $0.39 \log \mathrm{CFU} / \mathrm{g}$ fish and $5.0 \pm 0.4 \mathrm{log} \mathrm{CFU} / \mathrm{g}$ fish, respectively. However, no differences $(P>0.05)$ in microbial proliferation were found between UT and FS samples when the entire storage period was evaluated. These results were unexpected, since the results of previous research had shown an impact of FS treatment on lowering the initial microbial levels in tuna. While similar microbial growth trends to this study were observed in tilapia, where no differences were found over storage time at room temperature and refrigerated storage temperature (Leydon and others 2005), other research has shown an impact of treatment on the initial microbial load in mahi mahi (Kristinsson and others 2007) and tuna (Ludlow and others 2004; Kristinsson and others 2008). Kristinsson and others (2007) showed that while lower $(P<0.05)$ microbial concentrations were determined for FS-treated mahi mahi during initial storage at $4^{\circ} \mathrm{C}$, no differences $(P>0.05)$ were determined between UT and
FS product after $8 \mathrm{~d}$ of storage. Application of Clearsmoke (FS) to yellowfin tuna was also shown by Kristinsson and others (2008) to depress microbial growth. However, in some of the studies, while the same FS was applied, it was done in a controlled laboratory environment, using a commercial cylinder as the source of the FS gas at 18\% CO (Kristinsson and others 2006b, 2008). The gas applied in this study reflected commercial application in a pilot plant facility using $1 \mathrm{~d}$ old compressed FS gas with a CO concentration of $16 \%$. This variation could account for the difference in the results obtained reflecting application parameters and/or level of gas saturation in the product (not evaluated in this study). This disagreement in microbial profiles reported by the different studies is noteworthy since they could reflect the importance of standardized protocol for FS application and its ultimate impact on microbial assessment. In this study, filtered smoke did not appear to impact microbial proliferation either initially or during prolonged storage at the temperatures evaluated.

The other quality indices measured did not show a quality profile impact of treatment over untreated samples during storage at the different storage temperatures. Accumulation of apparent ammonia, with the exception of room temperature storage, and TVB-N in UT and FS tuna samples did not differ $(P>0.05)$ during storage (Figure 2 to 4 ). FS-treated product did have slightly higher apparent ammonia at time zero, $19 \mathrm{mg} / 100 \mathrm{~g}$ compared with $16.7 \mathrm{mg} / 100 \mathrm{~g}$ for untreated product, and significantly greater $(P<0.05)$ accumulation during room temperature storage.

A notable exception to the lack of difference in quality profile indicators between FS and UT samples was for lipid oxidation. Lipid oxidation indicators were lower $(P<0.05)$ for treated samples at room temperature and iced for POV values (Figure 5) and at all storage temperatures for TBARS (Figure 6). As expected, these values were lower at lower storage temperatures $(P<0.05)$. The FS treatment depressed the oxidative rancidity development $(P<0.05)$ during all storage temperatures evaluated. Other

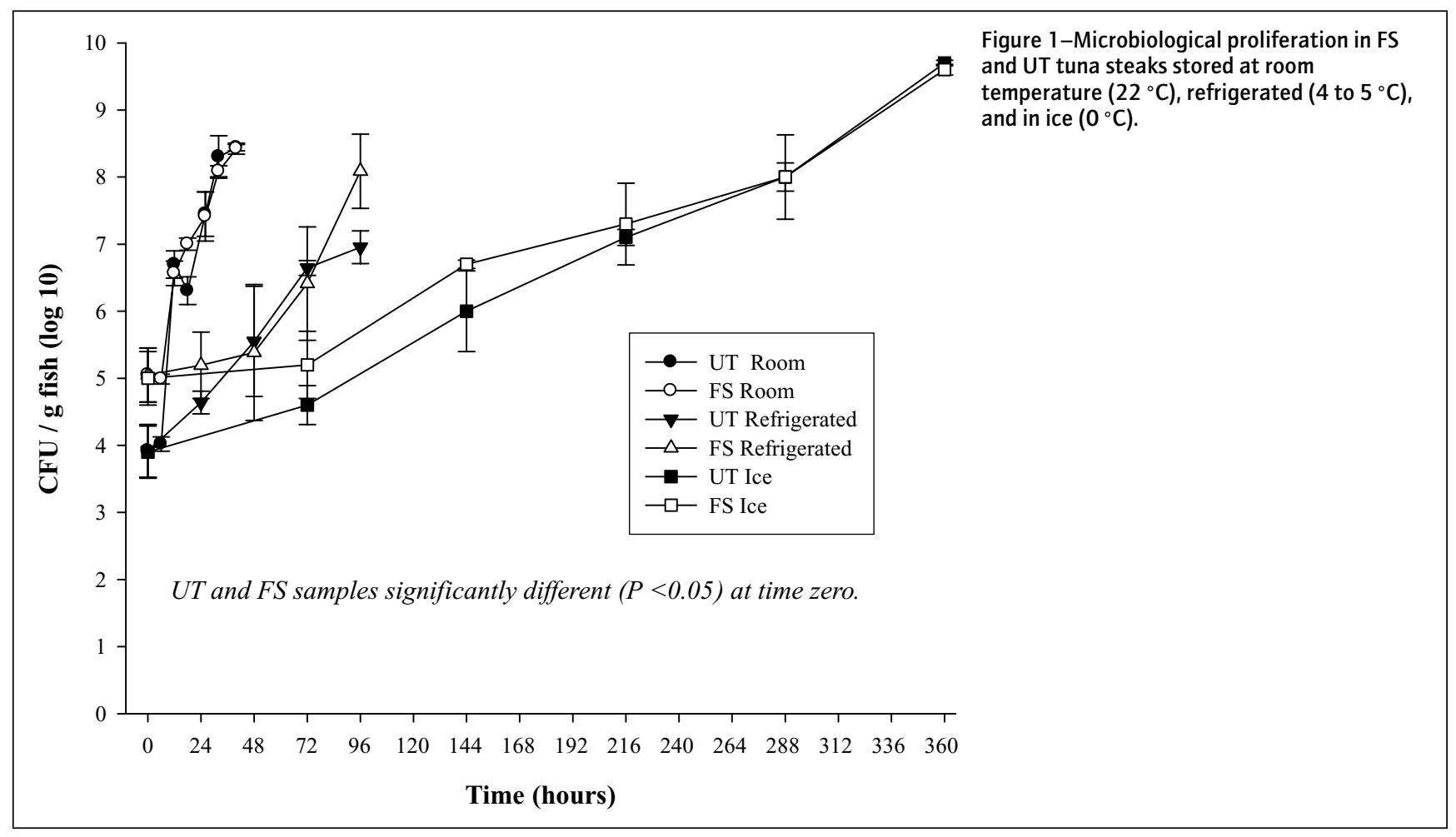


researchers have also shown that $\mathrm{CO}$ and/or FS treatments, when compared with untreated products, effectively depressed lipid oxidation in mahi mahi (Kristinsson and others 2007), tuna (Ludlow and others 2004), and Spanish mackerel (Garner and Kristinsson 2004). The major components involved in lipid oxidation of fish muscle are the heme proteins, hemoglobin, and myoglobin (Richards and Hultin 2002; Richards and Dettmann 2003;
Kristinsson and others 2007; Faustman and others 2010). Stabilization of heme proteins would be expected to reduce lipid oxidation rates (Kristinsson and others 2007) as the relationship between myoglobin and lipid oxidation in yellowfin tuna has been documented (Lee and others 2003; Faustman and others 2010). Other components of FS include carbon dioxide $\left(\mathrm{CO}_{2}\right)$, and gaseous phenolics (Kowalski 1999; Kristinsson and others 2007). Carbon
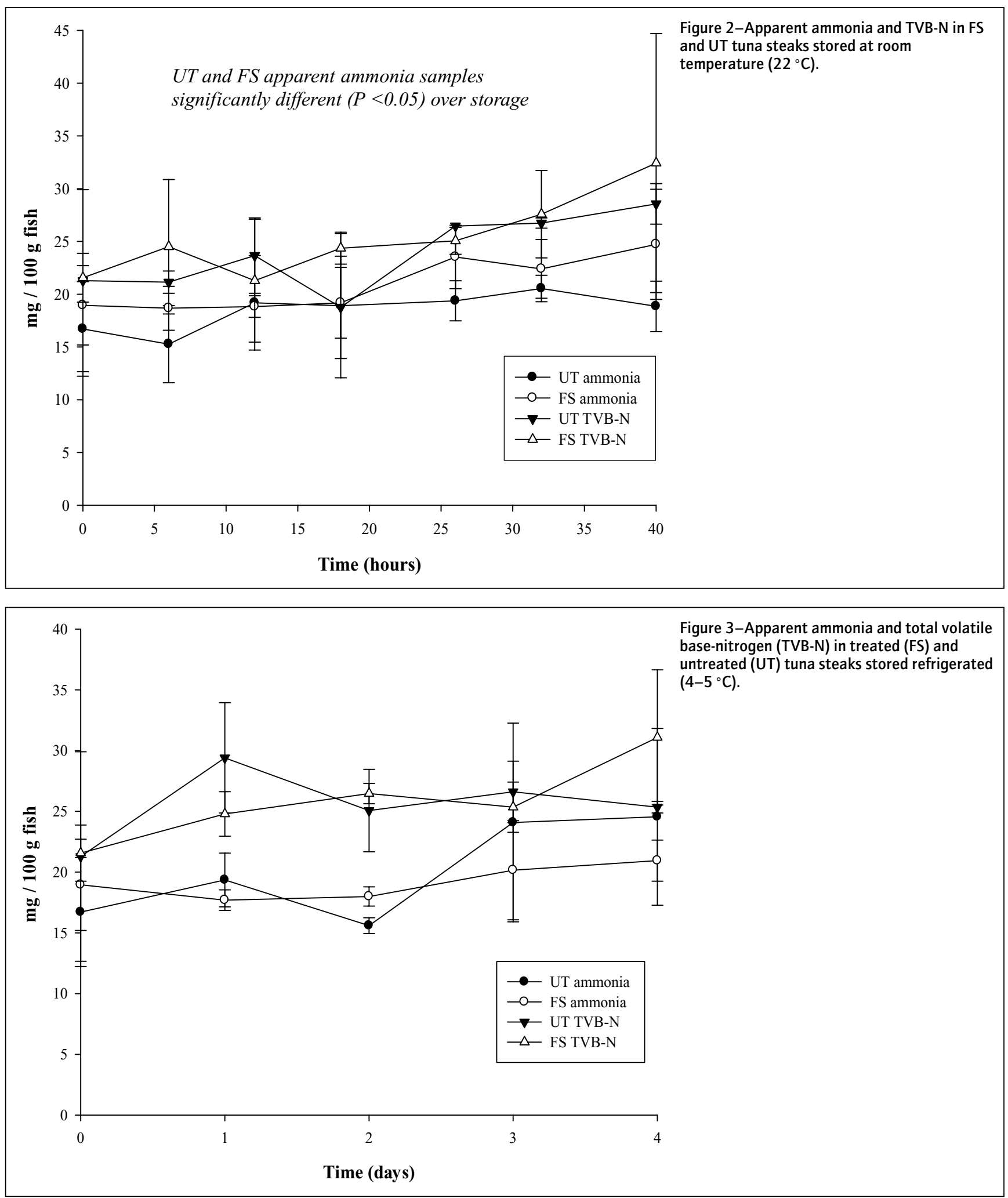
dioxide and $\mathrm{N}_{2}$ might impact bacterial growth, but these gases have not shown a strong correlation with color and/or lipid oxidation (Kristinsson and others 2006a). Phenolics may contribute to the antioxidant impact of the FS. Although many of the particulate phenols are removed during filtration, some minor gaseous phenols remain; however, their antioxidative function would be minor compared to CO (Kristinsson and others 2006a).

Significantly $(P<0.05)$ different expert sensory evaluations are shown for UT and FS tuna steaks stored at all trial temperatures in Figure 7 to 9 . The chemical and microbial quality profile

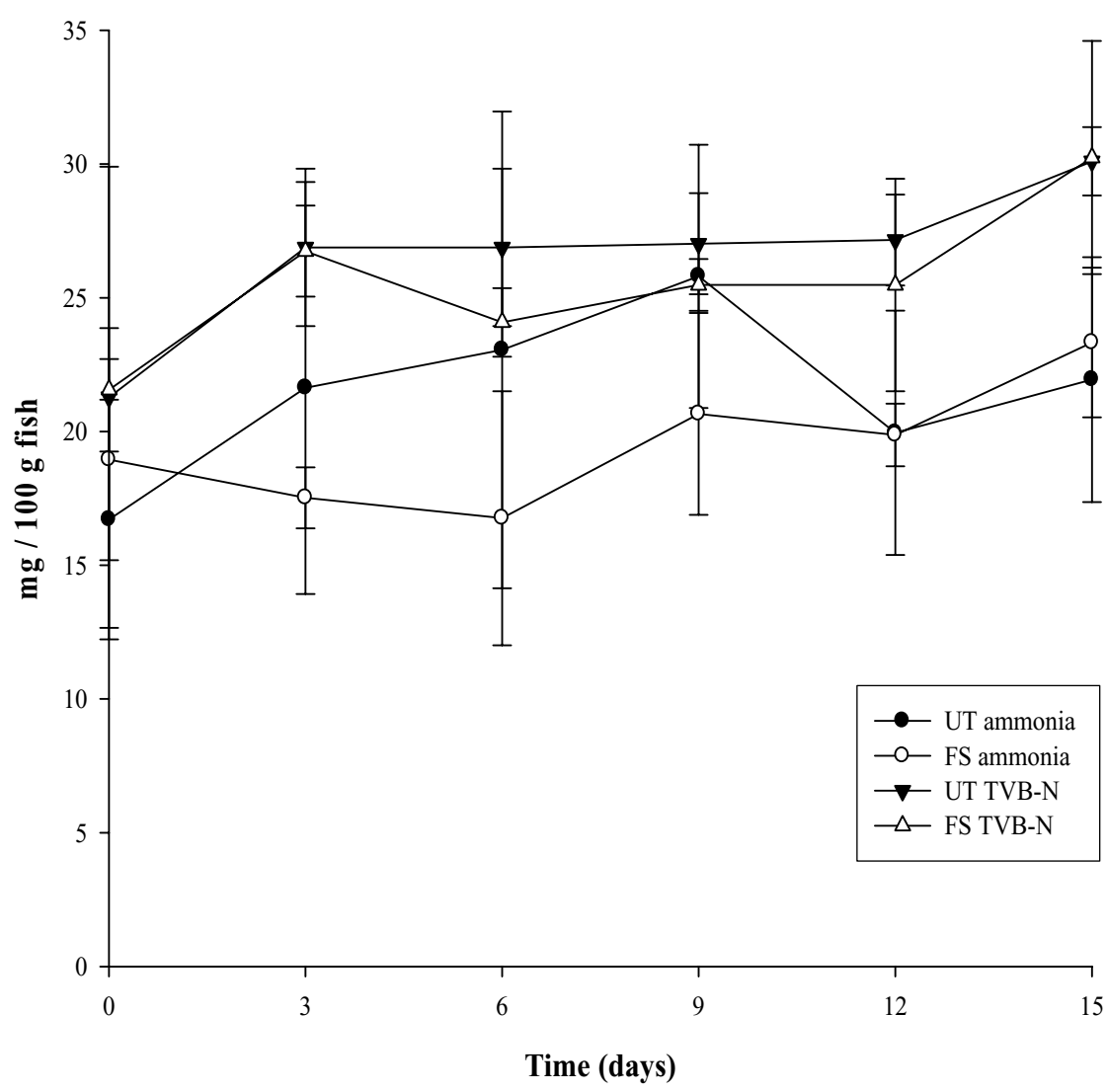

Figure 4-Apparent ammonia and TVB-N in FS

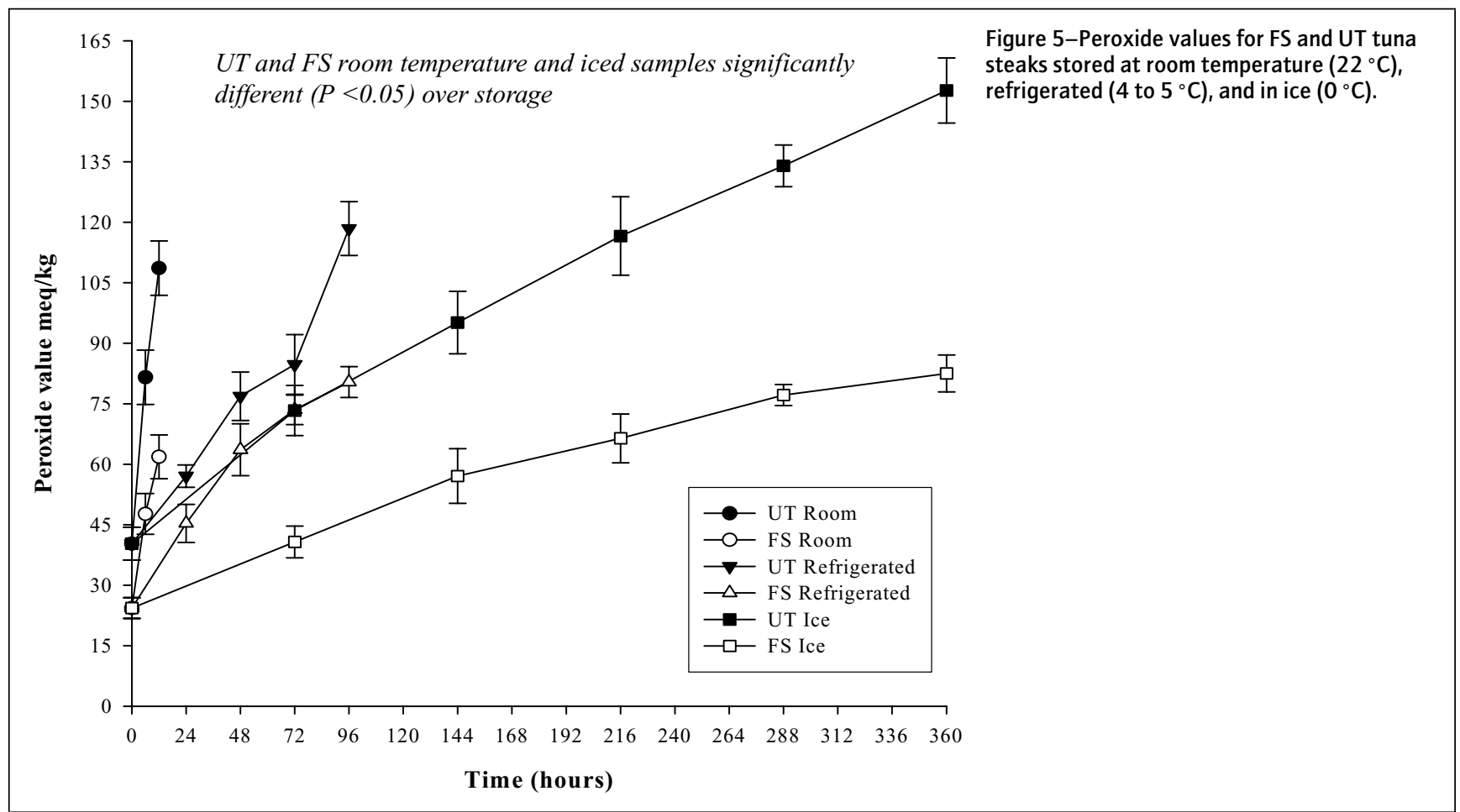


measurements for refrigerated (Figure 7) and iced (Figure 8) tuna steaks were supported by the sensory evaluation, where the time of rejection or borderline acceptability $(\geq 50 \mathrm{~mm}$ ) of the tuna steaks were not different between UT and FS products. Similar results were obtained for mahi-mahi where FS and UT samples, stored at $4{ }^{\circ} \mathrm{C}$, both crossed above the limit of sensory acceptability at the same time (Kristinsson and others 2007). Both UT and FS samples were at borderline quality after $4 \mathrm{~d}$ at refrigeration temperatures and were considered unacceptable after $15 \mathrm{~d}$ on ice, in agreement with the microbial proliferation profile observed. However, when fish was stored at abusive or room temperature (Figure 9), sensory assessment indicated significant differences in acceptability between UT and FS, with UT samples having accelerated unacceptable sensory scores. During the storage trials,
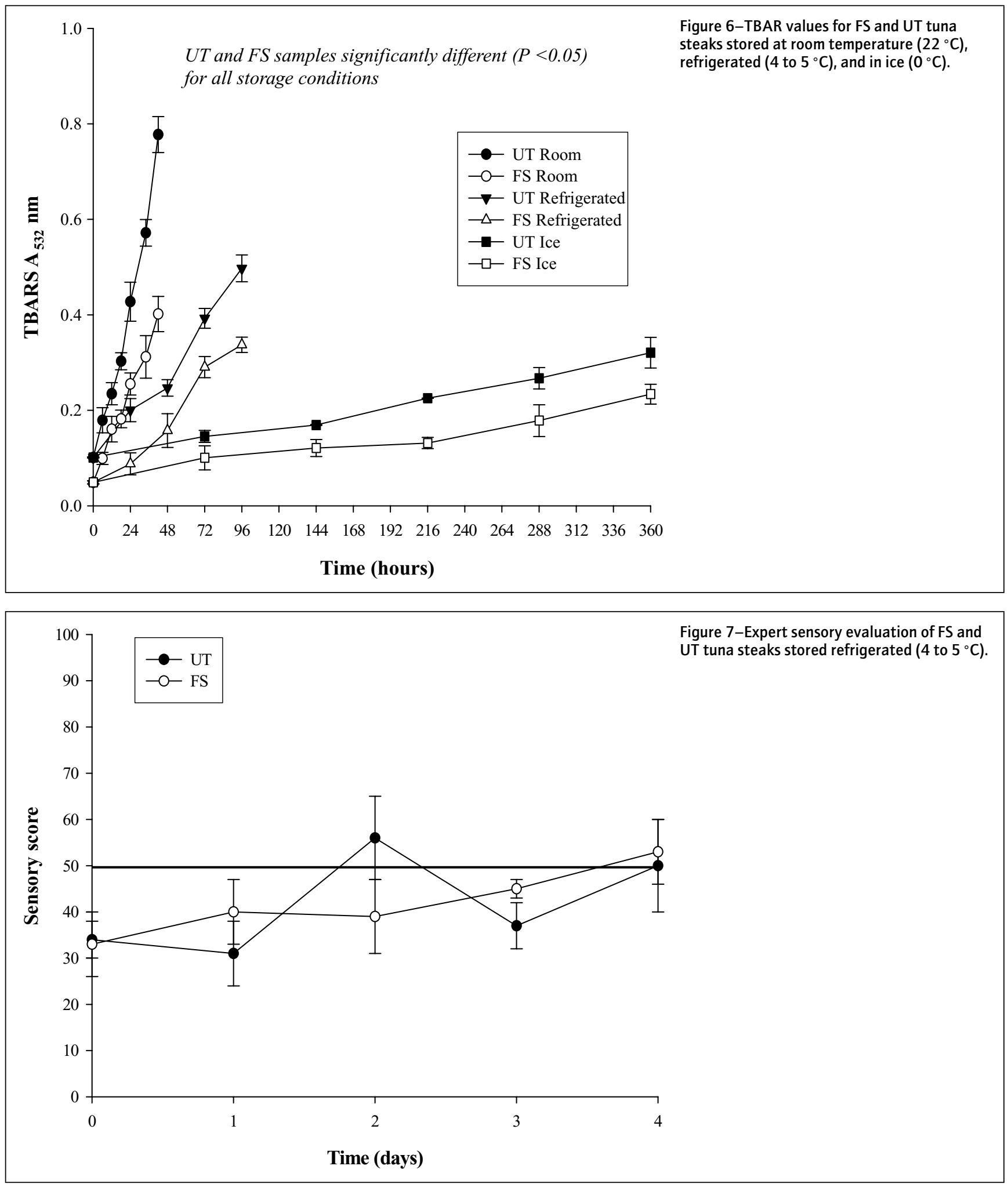
in addition to the documented added benefit of FS treatment, developed quickly and dramatically to levels that may have been lower temperatures would also suppress the development of oxidative rancidity. Concentrations of oxidative compounds formed (Figure 5 and 6) at lower temperatures, though lower in FS-treated products than UT, may not have been sufficiently high enough in either product to have impacted expert sensory assessment of UT or FS tuna. However, at room temperature oxidative rancidity more easily identified by sensory analysts in the UT product. This could account for the sensory differences $(P<0.05)$ obtained between UT and FS tuna stored at room temperature.

Finally, color is an important quality attribute of meat and seafood, especially for tuna where the market value is based on muscle appearance and color. Lightness $\left(L^{*}\right)$, yellowness $\left(b^{*}\right)$, and
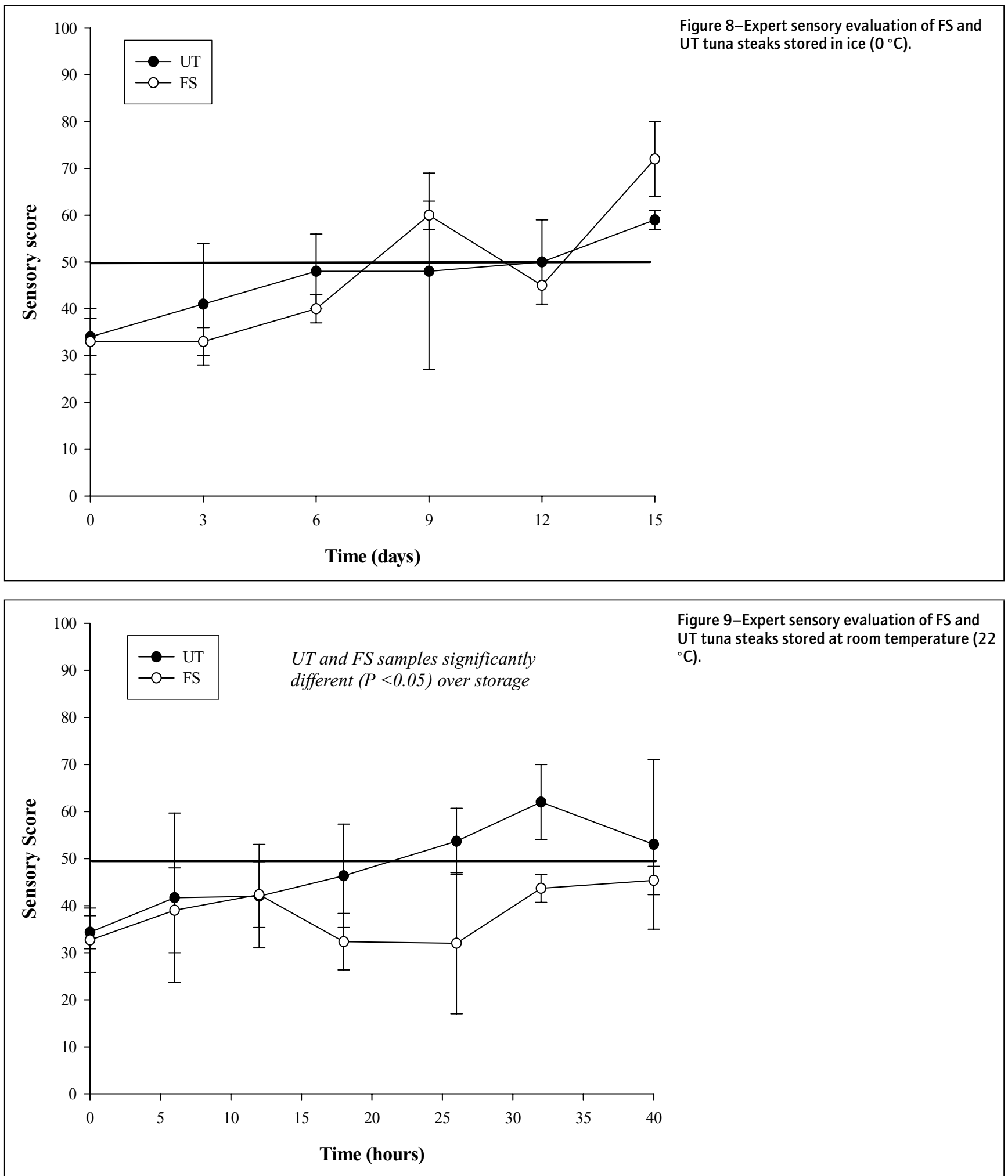
redness $\left(a^{*}\right)$ are presented in Table 1 to 3 , respectively. No differences were observed for initial $L^{*}$ and $b^{*}$ color values between UT and FS tuna (Table 1 and 2, respectively). Overall, there were no clear trends that showed that treatment affected $L^{*}$ or $b^{*}$ color values consistently. There were no changes in $L^{*}$ for any of the storage conditions for FS fish (Table 1). While $b^{*}$ showed a slight significant $(P<0.05)$ increase in FS tuna during storage in ice, this was not observed for other samples evaluated (Table 2). No effect of treatment on $L^{*}$ and $b^{*}$ was reported by other researchers (Kristinsson and others 2006b). However, redness, $a^{*}$ value, which is considered an important color parameter since red color is highly valued for quality, was impacted by the filtered smoke treatment for all storage temperatures. Treatment significantly $(P<0.05)$ increased $a^{*}$ at time zero, with values of $5.1 \pm 1.2$ and $9.7 \pm$ 1.4 for UT and FS tuna, respectively (Table 3). These results agree with Kristinsson and others (2006c), who reported an approximate 2 -fold increase in $a^{*}$ for tuna steaks, grades A and B, treated with either $100 \%$ CO or FS ( $20 \% \mathrm{CO})$. When grade C brown tuna steaks were treated with $100 \%$ CO, the red color was restored. However, color restoration for grade $\mathrm{C}$ steaks did not occur with FS (20\% CO; Kristinsson and others 2006c). A significant $(P<$ $0.05)$ decrease in $a^{*}$ was observed for the UT product during all storage temperatures evaluated in this study. This initial discoloration difference may be due to the impact of oxidation of heme proteins due to cutting and freezing, with the color stabilized by the treatment of tissue with FS (Anderson and Wu 2005). However, there were no significant $(P>0.05)$ changes in $a^{*}$ for treated tuna steaks during any of the storage temperatures evaluated.

Discoloration in stored meat is generally attributed to the change in the myoglobin redox status (Richards and Hultin 2002;
Faustman and others 2010). The redox state of the heme iron dictates the color of fish muscle (Lee and others 2003). The reduced ferrous heme iron ion $(\mathrm{Fe} 2+)$ in the myoglobin molecule is prone to oxidation to the ferric form $(\mathrm{Fe} 3+)$, which affects the color, taste, and texture (Faustman and Cassens 1990; Chan and others 1998). The CO component of FS binds with the heme iron of myoglobin forming carboxymyoglobin, which is more resistant to oxidation than oxymyoglobin because $\mathrm{CO}$ has a stronger binding affinity to the heme iron than oxygen does (Livingston and Brown 1981; Kristinsson and others 2007). While formation of Maillard products could contribute to surface browning through aldehyde groups of lipid oxidation products and amines, this has been more typically associated with cooked or freeze-dried meat products. Conversion of red ferrous oxy-heme proteins (that is, myglobin, hemoglobin) to brownish ferric met-heme proteins has been attributed to the color changes typically observed in fresh/frozen tuna (Chow and others 2004; Sohn and others 2005; Thiansilakul and others 2011). While it has been well documented that FS and/or CO treatment stabilizes red color in tuna, mahi mahi, and Spanish mackerel during frozen or refrigerated storage, research has indicated that redness faded upon aerobic storage albeit at a much slower rate that what occurs in untreated fish (Kristinsson and others 2006b). The color change with storage time did not occur in this study. As stated previously, the difference seen in color stability between the current study and that reported by other researchers could be attributed to treatment methodology. Therefore, if applications of FS are not uniformly applied and different procedures are used, then assurances of the quality profiles of fish, as mirrored by color changes, may not be the same.

Table 1-Changes of lightness $\left(L^{*}\right)$ color value in untreated and filtered smoked tuna steaks stored and sampled at 3 different time/temperature conditions: room temperature $\left(22^{\circ} \mathrm{C}\right)$ sampled hourly, refrigerated $\left(4\right.$ to $\left.5{ }^{\circ} \mathrm{C}\right)$ sampled daily, and refrigerated on ice $\left(0^{\circ} \mathrm{C}\right)$ sampled daily.

Untreated Tuna

Sampling time/storage temperature

\begin{tabular}{|c|c|c|c|c|c|c|c|c|c|c|c|}
\hline & & & & & & & & & & & \\
\hline \multicolumn{2}{|c|}{ Hour $/ 22^{\circ} \mathrm{C}$} & \multicolumn{2}{|c|}{ Day/4 to $5^{\circ} \mathrm{C}$} & \multicolumn{2}{|c|}{ Day $/ 0{ }^{\circ} \mathrm{C}$} & \multicolumn{2}{|c|}{ Hour $/ 22{ }^{\circ} \mathrm{C}$} & \multicolumn{2}{|c|}{ Day/4 to $5^{\circ} \mathrm{C}$} & \multicolumn{2}{|c|}{ Day/0 ${ }^{\circ} \mathrm{C}$} \\
\hline $0^{\mathrm{a}}$ & $32.3 \pm 2.7$ & 0 & $32.3 \pm 2.7$ & 0 & $32.3 \pm 2.7$ & $0^{a}$ & $32.2 \pm 1.9$ & 0 & $32.2 \pm 1.9$ & 0 & $32.2 \pm 1.9$ \\
\hline 6 & $39.6 \pm 1.4$ & 1 & $33.3 \pm 2.0$ & 3 & $35.4 \pm 4.2$ & 6 & $36.8 \pm 4.7$ & 1 & $31.3 \pm 1.1$ & 3 & $32.2 \pm 1.5$ \\
\hline 12 & $33.3 \pm 2.1$ & 2 & $31.9 \pm 1.6$ & 6 & $37.4 \pm 2.8$ & 12 & $33.9 \pm 1.9$ & 2 & $31.8 \pm 0.7$ & 6 & $31.8 \pm 0.7$ \\
\hline 18 & $31.5 \pm 1.3$ & 3 & $35.5 \pm 3.1$ & 9 & $36.7 \pm 3.8$ & 18 & $34.0 \pm 1.7$ & 3 & $34.3 \pm 1.4$ & 9 & $34.5 \pm 0.7$ \\
\hline 26 & $36.3 \pm 2.8$ & 4 & $33.3 \pm 3.1$ & 12 & $33.8 \pm 2.0$ & 26 & $34.0 \pm 1.5$ & 4 & $31.9 \pm 0.5$ & 12 & $32.0 \pm 1.0$ \\
\hline 32 & $36.1 \pm 0.8$ & & & 15 & $34.4 \pm 2.8$ & 32 & $35.5 \pm 3.1$ & & & 15 & $34.4 \pm 2.9$ \\
\hline 40 & $35.3 \pm 3.1$ & & & & & 40 & $36.2 \pm 1.4$ & & & & \\
\hline \multicolumn{12}{|c|}{ Significant difference $(P<0.05)$ in lightness during storage } \\
\hline & YES & & $\mathrm{NO}$ & & NO & & $\mathrm{NO}$ & & $\mathrm{NO}$ & & $\mathrm{NO}$ \\
\hline
\end{tabular}

Table 2- Changes of yellowness $\left(b^{*}\right)$ color value in untreated and filtered smoked tuna steaks stored and sampled at 3 different time/temperature conditions: room temperature $\left(22^{\circ} \mathrm{C}\right)$ sampled hourly, refrigerated $\left(4\right.$ to $\left.5{ }^{\circ} \mathrm{C}\right)$ sampled daily, and refrigerated on ice $\left(0^{\circ} \mathrm{C}\right)$ sampled daily.

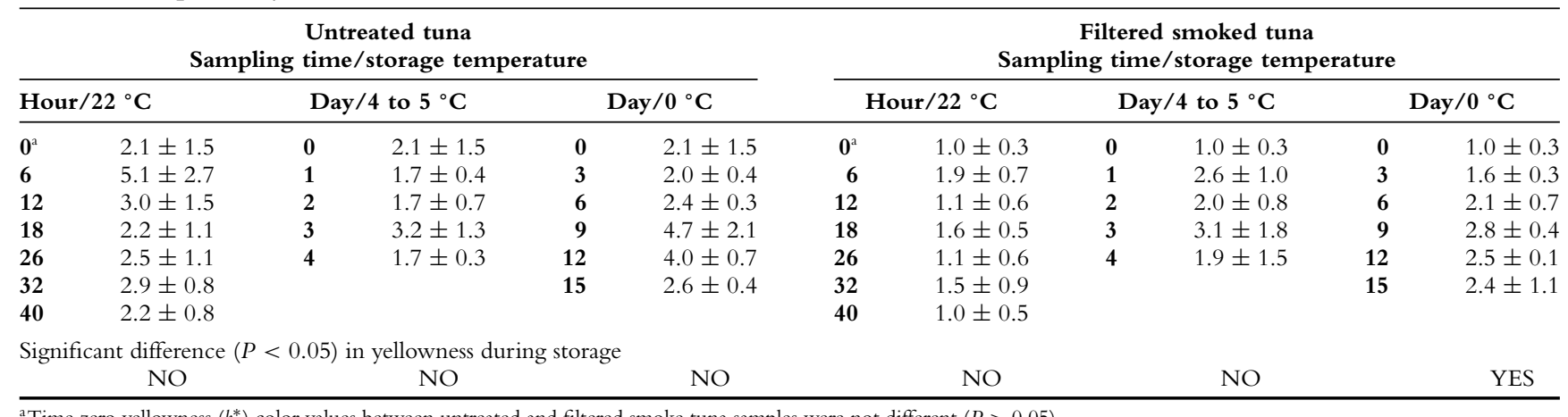

\footnotetext{
${ }^{a}$ Time zero yellowness $\left(b^{*}\right)$ color values between untreated and filtered smoke tuna samples were not different $(P>0.05)$
} 
Table 3-Changes of redness $\left(a^{*}\right)$ color value in untreated and filtered smoked tuna steaks stored and sampled at 3 different time/temperature conditions: room temperature $\left(22{ }^{\circ} \mathrm{C}\right)$ sampled hourly, refrigerated $\left(4\right.$ to $\left.5{ }^{\circ} \mathrm{C}\right)$ sampled daily, and refrigerated on ice $\left(0{ }^{\circ} \mathrm{C}\right)$ sampled daily.

\begin{tabular}{|c|c|c|c|c|c|c|c|c|c|c|c|}
\hline \multicolumn{6}{|c|}{$\begin{array}{l}\text { Untreated tuna } \\
\text { Sampling time/storage temperature }\end{array}$} & \multicolumn{6}{|c|}{$\begin{array}{l}\text { Filtered smoked tuna } \\
\text { Sampling time/storage temperature }\end{array}$} \\
\hline \multicolumn{2}{|c|}{ Hour $/ 22{ }^{\circ} \mathrm{C}$} & \multicolumn{2}{|c|}{ Day/4 to $5{ }^{\circ} \mathrm{C}$} & \multicolumn{2}{|c|}{ Day $/ 0{ }^{\circ} \mathrm{C}$} & \multicolumn{2}{|c|}{ Hour $/ 22{ }^{\circ} \mathrm{C}$} & \multicolumn{2}{|c|}{ Day/4 to $5{ }^{\circ} \mathrm{C}$} & \multicolumn{2}{|c|}{ Day $/ 0{ }^{\circ} \mathrm{C}$} \\
\hline $0^{\mathrm{a}}$ & $5.1 \pm 1.2$ & $\mathbf{0}$ & $5.1 \pm 1.2$ & 0 & $5.1 \pm 1.2$ & $0^{\mathrm{a}}$ & $9.7 \pm 1.4$ & 0 & $9.7 \pm 1.4$ & 0 & $9.7 \pm 1.4$ \\
\hline 6 & $5.5 \pm 1.5$ & 1 & $4.3 \pm 0.8$ & 3 & $3.3 \pm 0.7$ & 6 & $11.3 \pm 0.2$ & 1 & $11.2 \pm 3.7$ & 3 & $9.3 \pm 0.5$ \\
\hline 12 & $4.0 \pm 0.1$ & 2 & $2.7 \pm 0.7$ & 6 & $3.0 \pm 0.5$ & 12 & $9.9 \pm 0.5$ & 2 & $10.6 \pm 1.3$ & 6 & $10.3 \pm 2.3$ \\
\hline 18 & $3.6 \pm 0.8$ & 3 & $3.9 \pm 0.4$ & 9 & $3.6 \pm 0.9$ & 18 & $10.6 \pm 1.1$ & 3 & $11.1 \pm 2.9$ & 9 & $9.8 \pm 1.5$ \\
\hline 26 & $3.1 \pm 1.2$ & 4 & $3.1 \pm 0.2$ & 12 & $3.4 \pm 0.3$ & 26 & $9.2 \pm 0.7$ & 4 & $9.3 \pm 2.6$ & 12 & $10.4 \pm 0.5$ \\
\hline 32 & $2.7 \pm 0.7$ & & & 15 & $2.5 \pm 0.5$ & 32 & $10.5 \pm 0.2$ & & & 15 & $10.0 \pm 0.2$ \\
\hline 40 & $3.4 \pm 0.3$ & & & & & 40 & $10.0 \pm 1.1$ & & & & \\
\hline \multicolumn{12}{|c|}{ Significant difference $(P<0.05)$ in redness during storage } \\
\hline & YES & & YES & & YES & & $\mathrm{NO}$ & & $\mathrm{NO}$ & & $\mathrm{NO}$ \\
\hline
\end{tabular}

${ }^{a}$ Time zero redness $\left(a^{*}\right)$ color values between untreated and filtered smoke tuna samples were significantly different at $P<0.05$.

\section{Conclusions}

Microbial, chemical and expert sensory analyses all showed similar patterns of quality and spoilage changes during storage for UT- and FS-treated tuna. The impact on enhanced lipid stability through decreased oxidation rates in FS-treated samples would be important in the protection of the omega-3 fatty acids, important to health. However, while color, as determined by redness, faded during storage of UT tuna and paralleled the laboratory and sensory assessments, there were no significant changes in red color in the FS tuna over the storage periods, regardless of temperature, even if all other quality profile indicators revealed a declining product. Furthermore, in this study, FS treatment did not increase the shelf life of the tuna when stored at refrigerated or iced temperatures. Therefore, a general statement indicating that all FS treatments would extend shelf life or depress initial microbial growth would not be appropriate. Finally, the lack of color change, a primary sensory assessment used by consumers when purchasing this product, confirms that FS application could mask a lower quality product in the marketplace.

\section{Acknowledgments}

This study was funded by a grant from National Oceanic and Atmospheric Administration National Marine Fisheries Service (NOAA/NMFS) under grant no. NA16FD2301. The project was assigned contribution no. 5254 by the U.S. Dept. of Agriculture at the Univ. of Rhode Island. This research was supported by the Univ. of Rhode Island/Agricultural Experiment Station (URI/AES) and RI Sea Grant.

\section{References}

Anderson CR, Wu W-H. 2005. Analysis of carbon monoxide in commerically treated tun (Thunnus spp.) and mahi-mahi (Coryphaena hippurus) by gas chromatography/mass spectrometry. J Agric Food Chem 53:7019-23.

[AOAC] Assoc. of Official Analytical Chemists. 1990. AOAC official method 966.23. Chapter 17. In: Helrich K, editor. Official methods of analysis of AOAC Intl., 15th ed. Arlington, Va. AOAC Intl.

[AOAC]. Assoc. of Official Analytical Chemists. 1995. AOAC official method 980.10. In Cunniff P, editor. Official methods of analysis of AOAC Intl., 16th ed. Gaithersburg, Md. AOAC Intl.

[AOAC]. Assoc. of Official Analytical Chemists. 2000. AOAC official method 999.01. Chapter 35. In: Horwitz W, editor. Official methods of analysis of AOAC Intl., 17th ed. Gaithersburg, Md.: AOAC Intl.

Banwart GJ. 1989. Basic food microbiology. New York: Van Nostrand Reinhold. 771 p.

Bartram PK. 1996. Proper processing and handling of raw tuna. In: Martin RE, Collette RL, Slavin JW, editors. Fish inspection quality control and HACCP: a global focus. New York: Taylor \& Francis Group. p 233-7.

Chan WKM, Joo S-T, Faustman C, Sun Q, Vieth R. 1998. Effect of Pseudomonas fluorescens on beef discoloration and oxymyoglobin oxidation in vitro. J Food Prot 61:1341-6.

Chow CJ, Ochiai Y, Watabe S. 2004. Effect of frozen temperature on autoxidation and aggregation of bluefin tuna myoglobin in solution, J Food Biochem 28:123-34.

Demir N, Kristinsson HG, Balaban MO, Otwell WS. 2004. Quality changes in mahi mahi (Coryphaena hippurus) fillets treated by different carbon monoxide concentrations and filtered smoke as assessed by color machine vision and lipid oxidation. IFT annual meeting, July 12-16, 2004, Las Vegas, Nev. Abstract 63-8. Chicago, Ill.: Institute of Food Technologist.

Faustman C, Cassens RG. 1990. The biochemical basis for discoloration in fresh meat: a review. J Muscle Foods 1:217-43.

Faustman C, Phillips A. 2001. Measurement of discoloration in fresh meat. In: Current protocols in food analytical chemistry. N.Y.: Wiley and Sons Inc.

Faustman C, Cassens RG, Schaefer DM, Buege DR, Williams SN, Sheller KK. 1989. Improvement of pigment and lipid stability in Holstein steer beef by dietary supplementation of vitamin E. J Food Sci 54:858-62.

Faustman C, Sun Q, Mancini R, Surendranath PS. 2010. Myoglobin and lipid oxidation interactions: mechanistic bases and control. Meat Sci 86:86-94.

FDA. 1995. Bacteriological analytical manual. Gaithersburg, Md.: AOAC Int.

Garner K, Kristinsson HG. 2004. Quality of Spanish mackerel (Scomberomorous maculates) muscle as affected by carbon monoxide and filtered smoke gas treatment. IFT annual meeting, July 12-16, 2004, Las Vegas, Nev. Abstract 49B-12. Chicago, Ill.: Institute of Food Technologist. Greene BE. 1969. Lipid oxidation and pigment changes in raw beef. J Food Sci 34:110-3.

Greene BE, Hsin I, Zipser MW. 1971. Retardation of oxidative color change in raw ground beef. J Food Sci 36:940-4.

[H.R. 3/26/2009] U.S. House of Representatives Committee on Energy and Commerce: May 26, 2009 Summary of discussion draft of the Food Safety Enhancement Act of 2009 [Internet]. Washington, D.C. Available from: http://energycommerce.house.gov/ Press_111/20090526/fsea_summary.pdf. Accessed 2010 August 3.

[H.R. July 2009] U.S. House of Representatives Committee on Energy and Commerce: July 2009 Summary of H.R. 2749, The Food Safety Enhancement Act of 2009 [Internet]. Washington, D.C. Available from: http://energycommerce.house.gov/ Press_111/20090729/hr2749_floorsummary.pdf. Accessed 2010 September 21.

ISO. 1993. Sensory analysis: general guidance for the selection, training and monitoring of assessors. Part 2: experts. ISO 8586-2.

Jay JM. 2000. Low-temperature food preservation and characteristics of psychrotrophic microoganisms. In: Jay JM, editor. Modern food microbiology. 6th ed. Md.: Aspen Publishers Inc. p 323-39.

Kowalski WR. 1999 Oct 26. Process for manufacturing tasteless super-purified smoke for treating seafood to be frozen and thawed. U.S. patent 5,972,401.

Kristinsson HG, Balaban MO, Otwell WS. 2006a. Microbial and quality consequences of aquatic foods treated with carbon monoxide and filtered wood smoke. In: Otwell WS, Kristinsson HG, Balaban MO, editors. Modified atmospheric processing and packaging of fish: filtered smokes, carbon monoxide and reduced oxygen packaging. Ames, Iowa: Blackwell Publishing. p 65-86.

Kristinsson HG, Balaban MO, Otwell WS. 2006b. The influence of carbon monoxide and filtered wood smoke on fish muscle color. In: Otwell WS, Kristinsson HG, Balaban MO, editors. Modified atmospheric processing and packaging of fish: filtered smokes, carbon monoxide and reduced oxygen packaging. Ames, Iowa: Blackwell Publishing. p 29-52.

Kristinsson HG, Balaban MO, Otwell WS. 2006c. Color enhancement and potential fraud in using CO. In: Otwell WS, Kristinsson HG, Balaban MO, editors. Modified atmospheric processing and packaging of fish: filtered smokes, carbon monoxide and reduced oxygen packaging. Ames, Iowa: Blackwell Publishing. p 127-40.

Kristinsson HG, Danyali N, Ua-Angkoon S. 2007. Effect of filtered wood smoke treatment on chemical and microbial changes in mahi mahi fillets. J Food Sci 72:C16-24.

Kristinsson HG, Crynen S, Yagiz Y. 2008. Effect of a filtered wood smoke treatment compared to various gas treatments on aerobic bacteria in yellowfin tuna steaks. LWT 41:746-50.

Lee S, Joo ST, Alderton AL, Hill DW, Faustman C. 2003. Oxymyoglobin and lipid oxidation in yellowfin tuna (Thunnus albacares) loins. J Food Sci 68:1664-8.

Ledafish. Info tuna quality. Available from: http://ledafish.com. Accessed 2011 May 18

Leydon NL, Suman SP, Ellis PC, Palmer C, Faustman LC, Pivarnik LF. 2005. Quality and safety assessment of time/temperature storage conditions for filtered smoked tilapia fillets produced for retail distribution. In: IFT National Meeting, July 16-20, New Orleans, La: Institute of Food Technologists, Chicago, Ill. Abstract. p 89A-16.

Livingston DJ, Brown WD. 1981. The chemistry of myoglobin and its reactions. Food Technol $5: 244-52$.

Ludlow N, Kristinsson HG, Balaban MO, Otwell WS, Welt B. 2004. Effect of different carbon monoxide and filtered smoke treatments on the quality and safety of yellowfin tuna (Thunnus albacares) muscle. IFT annual meeting, July 12-16, 2004, Las Vegas, Nev. Abstract 49B-26. Chicago, Ill.: Institute of Food Technologists.

Malle P, Tao SH. 1987. Rapid quantitative determination of trimethylamine using steam distillation. J Food Protect 50:756-60.

Malle P, Poumeyrol M. 1989. A new chemical criterion for the quality control of fish: trimethylamine/total volatile base nitrogen (\%). J Food Protect 52:419-23. 
Pivarnik LF, Thiam M, Ellis PE. 1998. Rapid determination of volatile bases in fish by using an ammonia ion-selective electrode. JAOAC Int 81:1011-22.

Pivarnik LF, Ellis PC, Wang X, Reilly T. 2001. Standardization of ammonia electrode method for evaluation seafood quality by correlation to sensory analysis. J Food Sci 66:945-52.

Poste LF, Mackie DA, Butler G, Larmond E. 1991. Laboratory methods for sensory analysis of food. In: Research Branch, Agriculture Canada, Publication 1864/E.

Reilly TI, York RK. 1993. Sensory analysis application to harmonization of expert assessors of fish products. Abstract. Presented at Quality Control and Quality Assurance for Seafood. Newport, Oreg., May 16-18.

Richards MP, Dettmann MA. 2003. Comparative analysis of different hemoglobins: autoxidation, reaction with peroxide, and lipid oxidation. J Agric Food Chem 51: 3886-91.

Richards MP, Hultin HO. 2002. Contributions of blood and blood components to lipid oxidation in fish muscle. J Agric Food Chem 50:555-64.

Shantha, NC, Decker EA. 1994. Rapid, sensitive, iron-based spectrophotometric methods for determination of peroxide values of food lipids. JAOAC Int 77:421-4.
Sims GG, Farn G, York RK. 1992. Quality indices for canned skipjack tuna: correlation of sensory attributes with chemical indices. J Food Sci 57:1112-5.

Sohn JH, Taki Y, Ushio H, Kohata T, Shioya I, Ohshima, T. 2005. Lipid oxidations in ordinary and dark muscles of fish: influences on rancid off-odor development and color darkening of yellowtail flesh during ice storage. J Food Sci 70:490-6.

Thiansilakul Y, Richards M, Benjakul S. 2011. Isolation, characterisation and stability of myoglobin from Eastern little tuna (Euthynnus affinis) dark muscle. Food Chem 124:25461.

Undeland I, Kristinsson HG, Hultin HO. 2004. Hemoglobin-mediated oxidation of waswhed minced cod muscle phospholipids: effect of $\mathrm{pH}$ and hemoglobin source. J Agric Food Chem 52:4444-51.

Venkitanarayanan KS, Faustman C, Hoagland T, Berry BW. 1997. Estimation of spoilage bacterial load in aerobically stored meat by fluorescein diacetate hydrolysis and resazurin reduction. J Food Sci 62:601-4.

Yin MC, Faustman C, Reisen JW, Williams SN. 1993. $\alpha$-Tocopherol and ascorbate delay oxymyoglobin and phospholipid oxidation in vitro. J Food Sci 58:1273-81. 